LBC 28.62

\title{
MAMMALIAN SURFACTANT PROTEIN HOMOLOGY BY DOMAIN COLLAGEN TYPE IV: EVOLUTIONARY AND FUNCTIONAL ANALYSIS
}

\author{
Kristina R. Bikmetova \\ Federal Scientific Centre of Agroecology, Complex Melioration and Protective Afforestation \\ of the Russian Academy of Sciences, Volgograd, Russian Federation
}

\begin{abstract}
The changes in the primary structures of proteins are strongly character due to evolution process. Some changes are beneficial and remain in the process of evolution, some ones are negatively affected to properties of the protein. Neutral changes in amino acid sequences can also occur, without affecting the protein and the body as a whole. Pulmonary surfactant is a surface-active lipoprotein complex (phospho-lipoprotein) formed by type II alveolar cells. The proteins and lipids that make up the surfactant have both hydrophilic and hydrophobic regions. As a medication, pulmonary surfactant is on the WHO Model List of Essential Medicines, the most important medications needed in a basic health system. The object of this study is surfactant-associated proteins. The aim of the study was to identify the relationship between the amino acid composition of the protein and its functions. The study of the structure of proteins was carried out using multiple alignment and building a phylogenetic tree. Proteins SP-A and SP-D are members of the C-type collectin family and consist of four domains: N-terminal sequence, collagen-like domain, carbohydrate recognition domain (CRD), "neck" between collagen-like and carbohydraterecognizing domains. Functionally, the most important are the C4 and CRD domains. Point mutations in these domains affect the change in the properties of proteins.
\end{abstract}

Key words: lung, surfactant, collagen type IV domain, phylogenetic tree.

УДК 575.86

ББК 28.62

\section{ГОМОЛОГИЯ БЕЛКОВ СУРФАКТАНТА МЛЕКОПИТАЮЩИХ ПО ДОМЕНУ COLLAGEN TYРЕ IV: ЭВОЛЮЦИОННЫЙ И ФУНКЦИОНАЛЬНЫЙ АНАЛИЗ}

\section{Кристина Романовна Бикметова}

Федеральный научный центр агроэкологии, комплексных мелиораций и защитного лесоразведения Российской академии наук, г. Волгоград, Российская Федерация

\begin{abstract}
Аннотация. В процессе эволюции происходит изменение первичных структур белков. Некоторые изменения являются полезными и сохраняются в процессе эволюции, некоторые отрицательно влияют на свойства белка. Так же могут происходить нейтральные изменения в аминокислотных последовательностях, никак не влияющие на белок и организм в целом.
\end{abstract}

Ключевые слова: легкие, сурфактант, домен Collagen type IV, филогенетическое дерево.

Введение. Сурфактант - это сложное поверхностно-активное вещество, выстилающее изнутри альвеолы, состоящее из фосфолипидов (около $90 \%$ ) и белков (около $10 \%$ ): гидрофильных SP-A (Surfactant Protein A) и SP-D и гидрофобных SP-B и SP-C. Фосфоли() пидная часть содержит $80 \%$ фосфатидилхо- лина и $9 \%$ фосфатидилглицерола $[1 ; 4 ; 7]$. Это вещество легких представляет собой секрет, который препятствует спадению легочных альвеол $[12 ; 18 ; 20]$. Эти свойства сурфактанта объясняются главным образом присутствием в нем фосфолипида дипальмитоилфосфатидилхолина, который образуется в легких 
доношенного плода непосредственно перед родами. Недостаток этого соединения в легких недоношенных детей является причиной расстройства у них дыхания $[2 ; 10 ; 14 ; 16]$. Компоненты липидного комплекса вместе с гидрофобными белками участвуют в снижении поверхностного натяжения в легких, а гидрофильные белки отвечают за регулирование механизмов иммунитета [8; 9; 13].

Основной белок сурфактанта (примерно 5,3 \% от всех белков сурфактанта) SP-A, как и SP-D, обладает выраженными иммуномодулирующими свойствами $[6 ; 15 ; 17 ; 19]$.

Белки SP-A и SP-D являются членами семейства коллектинов C-типа и состоят из четырех доменов:

1) N-терминальная последовательность;

2) коллагеноподобный домен (C4 или $\mathrm{NC} 1)$;

$3)$ углевод-узнающий домен (CRD, carbohydrate recognition domain);

4) «шейка» между коллагеноподобным и углевод-узнающим доменами [7].

Функционально наиболее важными являются домены C4 и CRD [3; 16]. Исследования показали, что замена всего лишь одной аминокислоты в процессе эволюции привела к тому, что SP-A2, у которого в 85 позиции коллагеноподобного домена находится Аргинин, проявляет более выраженные свойства, чем SP-A1, у которого в 85 позиции находится Цистеин [4; 14]. Дефектная структура коллагеноподобного домена является причиной развития таких тяжелых бронхолегочных заболеваний, как респираторный дистресс-синдром, врожденный альвеолярный протеиноз или интерстициальный альвеолит $[1 ; 3 ; 5]$.

Объектом исследования был выбран домен С4. Соответственно, предметом исследования - его функции, а также структурные изменения в процессе эволюции. Выбранный домен играет важную роль в формировании иммунного ответа легких.

Цель работы. Изучить, как изменение структуры белков сурфактанта млекопитающих по домену Collagen type IV повлияло на их функциональные свойства.

В рамках выбранной цели были сформулированы задачи:

1) построить филогенетическое дерево белков сурфактанта;
2) изучить функциональные свойства SPА и SP-D в зависимости от структурных особенностей Collagen type IV.

Материал и методы. Для достижения данной цели были проделаны следующие действия:

1. Анализ литературы. С помощью метода анализа литературы был осуществлен поиск различных источников информации, таких как статьи, учебники и аннотации, по теме сурфактант-ассоциированных белков.

2. Выбор объекта исследования. После анализа отобранных источников информации был выбрал объект исследования, домен гидрофильных сурфактант-ассоциированных белков - Collagen type IV.

3. Биоинформатический поиск. С помощью биоинформатического поиска была найдена информация, содержащаяся в статьях, учебниках и аннотациях, характеризующая домен Collagen type IV и его роль как в организме человека в целом, так и в гидрофильных сурфактант-ассоциированных белках в частности.

Далее был осуществлен поиск аминокислотных последовательностей гидрофильных сурфактант-ассоциированных белков, содержащих домен Collagen type IV. Поиск осуществлялся в базе данных UniProt по названию гена, кодирующего домен NC1 в гидрофильных сурфактантных белках у млекопитающих - SFTP. Так как существует 2 гидрофильных белка, SP$\mathrm{D}$ и SP-A, а белок SP-A в свою очередь подразделяется на SP-A1 и SP-A2, то поиск аминокислотных последовательностей проводился по трем генам: SFTPA1, SFTPA2 и SFTPD.

4. Построение филогенетического дерева. Используя три текстовых документа, содержащих аминокислотные последовательности белков SP-A1, SP-A2 и SP-D различных видов млекопитающих в формате FASTA, были построены множественные выравнивания этих белков. Основываясь на множественных выравниваниях, были построены три филогенетических дерева.

5. Анализ множественного выравнивания и филогенетического дерева. Структурные изменения оценивались визуально, а функциональные отслеживались с помощью поиска данных в статьях, посвященных соответствующим белкам.

6. Систематизация полученных данных. 
Результаты исследования. Поиск и сравнение первичных структур гидрофильных белков, множественное выравнивание и построение филогенетического дерева позволили найти следующие закономерности. Белки SP-A1 и SP-A2 находятся на одном эволюционном расстоянии от общего предка, это расстояние равно 0,015. Длина коллагеноподобного домена у этих белков одинакова - 73 аминокислоты. Между собой домены NC1 разных форм сурфактантного белка А-типа отличаются на несколько аминокислот. Сурфактант-ассоциированный белок D типа является более древним и находится на эволюционном расстоянии равном 1,196 . Поэтому он более широко распространен среди организмов, чем его гомологи. Средняя длина SP-D больше средней длины SP-A1 и SP-A2 примерно на 100 аминокислот. Коллагеноподобный домен имеет соответствующую длину равную 177 аминокислотам. Первичная структура SP-D сильно отличается от структуры белков SP-A1 и SP-A2.

Если рассматривать структуру коллагеноподобного домена отдельно у каждого из гидрофильных белков, то можно заметить, что внутри домена есть консервативные, практически не изменяющиеся в процессе эволюции, и неконсервативные участки, в которых часто происходят мутации. Именно за счет мутаций происходит изменение свойств белка, влияющих на его функции.

В сурфактант-ассоциированном белке A1-типа коллагеноподобный домен, если смотреть по множественному выравниванию, располагается с 37 по 109 аминокислоту и составляю в длину 72 аминокислоту. Консервативные участки располагаются с 49 по 58, с 70 по 73 аминокислоты, консервативной является каждая третья аминокислота домена глицин, за исключением 37, 74 и 77 позиций. Участок с 74 по 85 аминокислоту является наиболее измененным.

Домен NC1 белка SP-A2, если смотреть по множественному выравниванию, располагается с 43 по 115 аминокислоту и состоит из 72 аминокислоты. Консервативные участки располагаются с 46 по 49, с 51 по 64, с 66 по 74, с 76 по 79, с 89 по 95 аминокислоты, каждая третья аминокислота является консервативной, так как глицин - основная ами- нокислота коллагенопободных белков. SP-A2 не имеет больших изменяющихся участков с множественными мутациями, как белок SP-A1.

Коллагеноподобный домен в белке SP-D, если смотреть по множественному выравниванию, располагается с 59 по 237 аминокислоту, в длину составляет 177 аминокислот. Консервативные участки располагаются с 73 по 77 аминокислоту, 50, 61, 79, 102 и 114 аминокислоты и каждый третий глицин являются консервативными. В остальном структура домена содержит множество мутаций и различается практически у всех млекопитающих, у которых имеется белок SP-D. Среди гидрофильных белков сурфактанта SP-D имеет самую лучшую растворимость.

Заключение. Если рассматривать структуру коллагеноподобного домена отдельно у каждого из гидрофильных сурфактант-ассоциированных белков, то можно заметить, что внутри домена есть консервативные, практически не изменяющиеся в процессе эволюции, и неконсервативные участки, в которых часто происходят мутации. Именно за счет мутаций происходит изменение свойств белка, влияющих на его функции.

\section{СПИСОК ЛИТЕРАТУРЫ}

1. Вауэр, Р. Сурфактант в неоантологии. Профилактика и лечение респираторного дистресс-синдрома новорожденных : пер. с нем. / Р. Вауэр. - М. : Изд-во Мед. лит., 2011. - 192 с.

2. Гребенников, В. А. Респираторный дистресс-синдром у новорожденных / В. А. Гребенников, О. Б. Миленин, И. И. Рюмина. - М. : Вест. медицины, 1995. - $136 \mathrm{c}$.

3. Легкие в эмбриональном и раннем постнатальном периодах // Системы организма (гистология). - Электрон. текстовые дан. - Режим доступа: http://lekmed.ru/info/arhivy/sistemy-organizmagistologiya $-65 . \mathrm{html}$.

4. Микеров, А. Н. Роль сурфактантного белка А в иммунной защите легких / А. Н. Микеров // Фундаментальные исследования. - 2012. № 2. - C. 204-207.

5. Неонатология: Национальное руководство / под ред. Н. Н. Володина. - М. : ГЭОТАР-Медиа, 2007. $-848 \mathrm{c}$.

6. Синюкова, Т. А. Сурфактантные белки и их роль в функционировании дыхательной систе- 
мы / Т. А. Синюкова, Л. В. Коваленко // Вестник СурГУ Медицина. - 2011. - № 9. - С. 48-54.

7. Сулима, Е. Г. Новый сурфактант в Украине - Инфасурф (кальфактант) и его возможности в лечении РДС новорожденных / Е. Г. Сулима, Т. К. Знаменская, Ю. О. Поленцов // Современная педиатрия. -2009. - № 5 (27). - С. 140-146.

8. Физиологические и патофизиологические аспекты внешнего дыхания / Л. О. Гуцол [и др.]. Иркутск : ИГМУ, 2014. - 116 с.

9. Brinker, K. G. Surfactant protein A modulates the differentiation of murine bone marrow-derived dendritic cells / K. G. Brinker, H. Garner, J. R. Wright // Am J Physiol Lung Cell Mol Physiol. - 2003. Vol. 284. - P. 232-241.

10. Carreto-Binaghi, L. E. Surfactant proteins, SP-A and SP-D, in respiratory fungal infections: their role in the inflammatory response / L. E. CarretoBinaghi, M. Aliouat, M. L. Taylor // Respir Res. 2016. - Vol. 17. - P. 66.

11. Chroneos, Z. C. Pulmonary surfactant: an immunological perspective / Z. C. Chroneos, Z. SeverChroneos, V. L. Shepherd // Cell Physiol Biochem. 2010. - Vol. 25. - P. 13-26.

12. Crystal Structure of NC1 domains: Structural Basis for Type IV collagen / M. Sundaramoorthy [et al.] // The Journal of Biological Chemistry. - 2002. Vol. 277. - P. 31142-31153.

13. Decreased contents of surfactant proteins A and D in BAL fluids of healthy smokers / Y. Honda [et al.] //Chest. - 1996. - Vol. 109. - P. 1006-1009.

14. Differences in biochemical properties and in biological function between human SP-A1 and SP-A2 variants, and the impact of ozone-induced oxidation / G. Wang [et al.] // Biochemistry. -2004. - Vol. 43. P. 4227-4239.

15. Paananen, R. Surfactant proteins A and D in Eustachian tube epithelium / R. Paananen // American Journal of Physiology - Lung Cellular and Molecular Physiology. - 2001. - Vol. 281. - P. 660-667.

16. Pastva, A. M. Immunomodulatory Roles of Surfactant Proteins A and D / A. M. Pastva, J. R. Wright, K. L. Williams // Proceedings of the American Thoracic Society. - 2007. - Vol. 4, № 3. - P. 252-257.

17. Pulmonary surfactant, lung function, and endobronchial inflammation in cystic fibrosis / M. Griese [et al.] // Am J Respir Crit Care Med. 2004. - Vol. 170. - P. 1000-1005.

18. Sever-Chroneos, Z. Surfactant Protein A (SP-A)-mediated Clearance of Staphylococcus aureus Involves Binding of SP-A to the Staphylococcal Adhesin Eap and the Macrophage Receptors SP-A Receptor 210 and Scavenger Receptor Class A / Z. Sever-Chroneos // The Journal of Biological Chemistry. - 2011. - Vol. 286. P. 4854-4870.
19. Surfactant proteins A and D inhibit the growth of Gram-negative bacteria by increasing membrane permeability / $\mathrm{H}$. Wu [et al.] // J. Clin Invest. - 2003. - Vol. 111 - P. 1589-1602.

20. Wright, J. R. Pulmonary surfactant protein A stimulates chemotaxis of alveolar macrophage / J. R. Wright, D. C. Youmans // Am J Physiol Lung Cell Mol Physiol. - 1993. - Vol. 264. - P. 338-344.

\section{REFERENCES}

1. Vauer R. Surfactant $v$ neoantologii. Profilaktika $i$ lechenie respiratornogo distresssindroma novorozhdennykh [Surfactant in Neonatology. Prophylaxis and Treatment of Neonatal Respiratory Distress Syndrome]. Moscow, Izd-vo Meditsinskoy litwratuty, 2011. 192 p.

2. Grebennikov V.A., Milenin O.B., Ryumina I.I. Respiratornyy distress-sindrom u novorozhdennykh [Respiratory Distress Syndrome in Neonates]. Moscow, Vestnik Meditsiny Publ., 1995. 136 p.

3. Legkie v embrionalnom i rannem postnatalnom periodakh [Lungs in the embryonic and early postnatal periods]. Sistemy organizma (gistologiya)[Body systems (histology)]. URL: http://lekmed.ru/info/ arhivy/sistemy-organizma-gistologiya $-65 . \mathrm{html}$.

4. Mikerov A.N. Rol surfaktantnogo belka A v immunnoy zashchite lyogkikh [Role of Surfactant Protein A in Immune Defense of Lungs]. Fundamentalnye issledovaniya [Fundamental Research], 2012, no. 2, pp. 204-207.

5. Volodin N.N., ed. Neonatologiya: Natsionalnoe rukovodstvo [Neonatology: National Guide]. Moscow, GEOTAR-Media Publ., 2007. 848 p.

6. Sinyukova T.A., Kovalenko L.V. Surfaktantnye belki i ikh rol v funktsionirovanii dykhatelnoy sistemy [Surfactant Proteins and Their Role in the Functioning of the Respiratory System]. Vestnik Surgutskogo Gosudarstvennogo Universiteta. Meditsina [Med. J. Surgut St. Univ.], 2011, no. 9, pp. 48-54.

7. Sulima E.G., Znamenskaya T.K., Polencov Yu.O. Novyy surfaktant v Ukraine - Infrasurf (kalfaktant) v lechenii RDS novorozhdennykh [New Surfactant in Ukraine - Infasurf (Calfactant) and Its Possibilities in the Treatment of Neonatal RDS]. Sovremennaya Pediatriya [Current Pediatry], 2009, no. 5(27), pp. 140-146.

8. Gucol L.O., et al., eds. Fiziologicheskie $i$ patofiziologicheskie aspekty vneshnego dykhaniya [Physiological and Pathophysiological Aspects of External Respiration]. Irkutsk, IGMUPubl., 2014, 116 p.

9. Brinker K.G., Garner H., Wright J.R. Surfactant Protein A Modulates the Differentiation of Murine Bone Marrow-Derived Dendritic Cells. Am J Physiol Lung Cell Mol Physiol, 2003, vol. 284, pp. 232-241. 
10. Carreto-Binaghi L.E., Aliouat M., Taylor M.L. Surfactant Proteins, SP-A and SP-D, in Respiratory Fungal Infections: Their Role in the Inflammatory Response. Respir Res., 2016, vol. 17, p. 66.

11. ChroneosZ.C., Sever-ChroneosZ., Shepherd V.L. Pulmonary Surfactant:An Immunological Perspective. Cell Physiol Biochem, 2010, vol. 25, pp. 13-26.

12. Sundaramoorthy M., et al. Crystal Structure of NC1 Domains: Collagen. The Journal of Biological Chemistry, 2002, vol. 277, pp. 31142-31153.

13. Honda Y., et al. Decreased Contents of Surfactant Proteins. Chest, 1996, vol. 109, pp. 1006-1009.

14. Wang G.G., et al. Differences in Biochemical Properties and in Biological Function Between Human SP-A1 and SP-A2 Variants, and the Impact of OzoneInduced Oxidation. Biochemistry, 2004, vol. 43, pp. 4227-4239.

15. Paananen R. Surfactant Proteins A and D in the Eustachian Tube Epithelium. American Journal of Physiology - Lung Cellular and Molecular Physiology, 2001, vol. 281, pp. 660-667.
16. Pastva A.M., Wright J.R., Williams K.L. Immunomodulatory Roles of Surfactant Proteins A and D. Proceedings of the American Thoracic Society, 2007, vol. 4, no. 3, pp. 252-257.

17. Griese M., et al. Pulmonary Surfactant, Lung Function, and Endobronchial Cystic Fibrosis Inflammation. Am J Respir Crit Care Med, 2004, vol. 170, pp. 1000-1005.

18. Sever-Chroneos Z., et al. Surfactant Protein A (SP-A)-Mediated Adapters Repeater SPA Receptor 210 and Scavenger Receptor Class A. The Journal of Biological Chemistry, 2011, vol. 286, pp. 4854-4870.

19. Wu H. Surfactant proteins A and D inhibit the growth of Gram-negative bacteria by increasing membrane permeability. J. Clin Invest, 2003, vol. 111, pp. 1589-1602.

20. Wright J.R., Youmans D.C. Chemotaxis of Alveolar Macrophage. American Journal of Physiology - Lung Cellular and Molecular Physiology, 1993, vol. 264, pp. 338-344.

\section{Information about the Author}

Kristina R. Bikmetova, Junior Researcher, Laboratory of Biotechnology, Federal Scientific Centre of Agroecology, Complex Melioration and Protective Afforestation of the Russian Academy of Sciences, Prosp. Universitetskiy, 97, 400062 Volgograd, Russian Federation, c.bicmetowa@yandex.ru.

\section{Информация об авторе}

Кристина Романовна Бикметова, младший научный сотрудник лаборатории биотехнологий, Федеральный научный центр агроэкологии, комплексных мелиораций и защитного лесоразведения Российской академии наук, просп. Университетский, 97, 400062 г. Волгоград, Российская Федерация, c.bicmetowa@yandex.ru. 